\title{
Edge effect and phenology in Erythroxylum tortuosum (Erythroxylaceae), a typical plant of the Brazilian Cerrado
}

\author{
Ishino, MN. ${ }^{a}$, De Sibio, $P R^{a}{ }^{a}$ and Rossi, MN. ${ }^{b *}$

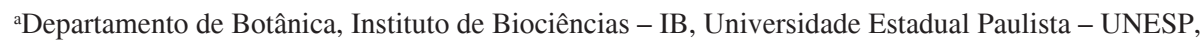 \\ Distrito de Rubião Junior, s/n, CEP 18618-970, Botucatu, SP, Brazil \\ ${ }^{b}$ Departamento de Ciências Biológicas, Universidade Federal de São Paulo - UNIFESP, \\ Rua Professor Artur Riedel, 275, Jardim Eldorado, CEP 09972-270, Diadema, SP, Brazil \\ *e-mail: rossi.unifesp@gmail.com \\ Received May 27, 2011 - Accepted September 19, 2011 - Distributed August 31, 2012
}

(With 2 figures)

\begin{abstract}
The edge of a forest fragment can be considered a zone of transition between the interior of the fragment and the surrounding habitat matrix. Plants along the edge are more exposed to disturbance and microclimate variation than interior plants, resulting in the so-called edge effect. In this study, we compared leaf area, fluctuating asymmetry and chemical (water, nitrogen and tannins) leaf traits between Erythroxylum tortuosum plants inhabiting the edge with those growing in the interior of a cerrado fragment in Brazil. We also describe the temporal variation in the vegetative and reproductive phenological events of E. tortuosum plants throughout the season. Nitrogen, leaf area and fluctuating asymmetry did not differ between the two plant groups. Young leaves of the edge plants had significantly higher levels of tannins and lower levels of water than those of interior plants. We suggest that differences in leaf chemical concentrations between edge and interior plants may occur due to factors such as light intensity, wind, temperature and leaf age rather than plant stress. With respect to plant phenology, most reproductive events occurred during the spring. Leaf buds and young leaves prevailed during the rainy season. In the dry season, however, the vegetative events decreased due to leaf senescence followed by leaf abscission.
\end{abstract}

Keywords: Cerrado, forest fragmentation, physical and chemical leaf traits, plant phenology, plant stress.

\section{Efeito de borda e fenologia em Erythroxylum tortuosum Mart. (Erythroxylaceae), uma planta típica do Cerrado brasileiro}

\begin{abstract}
Resumo
A borda de um fragmento florestal pode ser considerada uma zona de transição entre o interior do fragmento e a matriz de habitat. As plantas localizadas na borda estão mais expostas a distúrbios e variações microclimáticas do que as plantas do interior, resultando no chamado efeito de borda. Neste estudo, a área foliar, a assimetria flutuante e os caracteres químicos das folhas (água, nitrogênio e taninos) foram comparados entre plantas de Erythroxylum tortuosum situadas na borda e no interior de um fragmento de cerrado brasileiro. A variação temporal de eventos fenológicos vegetativos e reprodutivos de E. tortuosum também foi investigada durante o período de estudo. Nitrogênio, área foliar e assimetria flutuante não diferiram entre os dois grupos de plantas. As folhas jovens das plantas localizadas na borda apresentaram, significativamente, níveis mais altos de taninos e menores níveis de água do que as plantas do interior. Sugere-se que as diferenças nos conteúdos químicos foliares entre as plantas da borda e do interior devem ter ocorrido em razão de fatores como intensidade luminosa, vento, temperatura e idade foliar e não por causa do nível de estresse da planta. Com relação à fenologia, a maioria dos eventos reprodutivos ocorreu durante a primavera. Os botões foliares e as folhas novas prevaleceram durante a estação chuvosa. No entanto, na estação seca, os eventos vegetativos decresceram por causa da senescência das folhas, seguida pela abscisão foliar.
\end{abstract}

Palavras-chave: Cerrado, fragmentação florestal, caracteres foliares físicos e químicos, fenologia, estresse. 


\section{Introduction}

Habitat fragmentation due to anthropogenic activity has caused substantial change to the environment, threatening worldwide biodiversity and affecting the structure of biological communities (Bierregaard Junior et al., 1992; Fahrig, 2003; Paglia et al., 2006). In the process of fragmentation, continuous habitats are subdivided, and there is a considerable loss of both area and habitat quality, with a concomitant increase in habitat isolation (Mills, 1995; Hanski, 1999). Several components of these isolated fragments, such as patch area, environmental heterogeneity within fragments, the landscape surrounding habitat fragments (matrix), connectivity between suitable habitats, and the edge effect, are determinants of species persistence (Fahrig, 2003; Paglia et al., 2006; Del-Val et al., 2007). The edge effect refers to biotic and abiotic changes that occur along the boundaries of forest fragments due to biotic and abiotic differences between the fragment and the surrounding habitat matrix (Olifiers and Cerqueira, 2006). Alterations in light intensity, temperature, wind and humidity rate are some of the important microclimatic factors that contribute to the edge effect (Kapos, 1989; Bierregaard Junior et al., 1992). Local extinctions of some native plant species and alterations in biotic interactions have also been attributed to the edge effect (Gurevitch et al., 2002; Benítez-Malvido and Lemus-Albor, 2005).

Plants inhabiting the edges of fragmented habitats may experience high levels of stress, and comparisons of physical and chemical traits of plants found along the edge with those of plants in the interior should provide an indication of the degree of environmental stress caused by the edge effect. Particularly for chemical traits, water and nitrogen have been considered good predictors of the nutritional quality of foliage. Phenolic compounds such as tannins are usually associated with plant defences against insect herbivores (Schoonhoven et al., 2005); thus, in theory, plants with low levels of tannins in their leaves would experience high levels of herbivory, an important biotic stress-inducing factor.

Leaf size and leaf asymmetry are quite variable physical traits within populations and even within individual plants (overall, hereafter leaf asymmetry was considered a leaf trait), and measurement of these traits has been used to predict changes in environmental conditions (Brown and Lawton, 1991; Burns and Dawson, 2006; Roslin et al., 2006; Milligan et al., 2008; Shi and Cai, 2009). Fluctuating asymmetry (FA) describes the small but random variations in bilaterally symmetrical characters (Polak, 2003) and represents a potential measure of developmental instability (DI) in plants (Milligan et al., 2008; Puerta-Piñero et al., 2008). Because small deviations from perfect symmetry usually represent DI, FA has been used as an indicator of stress (Parsons, 1990; Martel et al., 1999; Alados et al., 2001; Cornelissen et al., 2003; Cornelissen and Stiling, 2005). Stress may not only modify physical traits directly but may also alter the concentrations of chemical compounds in plants that are responsible for changes in physical traits
(White, 1984; Black-Samuelsson and Andersson, 2003; Milligan et al., 2008).

\subsection{Study system and goals}

The Brazilian savannah cerrado is considered one of the world's richest ecosystems (Felfili and Silva-Júnior, 2001) and has been included in the world list of "hotspots" of biological diversity (Seligmann et al., 2007). However, this system has been substantially modified by anthropogenic causes, resulting in a mosaic of highly fragmented areas.

The plant family Erythroxylaceae is of wide subtropical and pantropical distribution, but only a single genus, Erythroxylum P. Browne, occurs in the neotropical region (Wanderley et al., 2002) where it is composed of approximately 180 species, 130 of which have been reported from Brazil. These tree and shrub species occur in forests as well as in the cerrado (Ribeiro et al., 1999). Erythroxylum tortuosum Mart. is a deciduous shrub-arboreal species typical of the cerrado community (Ishino et al., 2011). There is currently little information on the biology or ecology of this species. For example, the phenology of E. tortuosum plants has not been investigated.

Fragmentation is an ongoing process affecting the cerrado. In this study, we assessed whether comparing physical and chemical leaf traits between E. tortuosum plants along the edge and in the interior of a cerrado fragment that has been surrounded by cultivated fields (anthropogenic disturbance) would provide evidence of stress caused by the edge effect. Studying the edge effect in ecosystems like the cerrado is essential because stressinducing factors such as fire, a long dry season, and low soil nutritional quality are common (Hoffmann and Moreira, 2002; Miranda et al., 2002); therefore, some native plants may be stress tolerant and may not present differences in chemical and physical traits after a given disturbance. We also investigated the vegetative and reproductive phenology of E. tortuosum to provide basic information for future life history and ecological studies.

\section{Material and Methods}

\subsection{Study area}

Erythroxylum tortuosum individuals were observed in a cerrado fragment (176.7 ha) located within the Palmeirada-Serra Farm in the municipality of Pratânia, state of São Paulo, Brazil (22 $48^{\prime} 50^{\prime \prime} \mathrm{S}$ and $\left.48^{\circ} 44^{\prime} 35^{\prime \prime} \mathrm{W}\right)$. This region has a mesothermic climate with dry summers and wet winters. The average annual rainfall and temperature are $1534 \mathrm{~mm}$ and $20.3^{\circ} \mathrm{C}$, respectively, and the average annual daytime relative humidity is approximately $80 \%$ during the rainy season and 55\% during the dry season, when daily minimum relative humidity is approximately 15\% (Rodrigues and Machado, 2008). Fields surrounding the study area have been used mainly for cultivation of soybean, corn, Eucalyptus, Pinus, and sugarcane; thus, anthropogenic disturbance has been common adjacent to the fragment. All plants were located within four transects (each $20 \mathrm{~m}$ wide and advancing $150 \mathrm{~m}$ into the interior 
of the fragment). Transects were $100 \mathrm{~m}$ apart from each other, and 43 E. tortuosum individuals were marked with $5 \times 5 \mathrm{~cm}$ numbered metal labels.

\subsection{Edge effect on leaf traits}

To examine the edge effect on physical and chemical leaf traits, intact leaves were randomly collected from 14 plants distributed throughout the four transects in October and November 2005, when young leaves were predominant. Young leaves were the expanded bright green leaves appearing immediately following the opening of the leaf-buds. Of the study plants, six were on the edge of the fragment and eight were located in the interior. The edge plants were close to the road and at most $10 \mathrm{~m}$ into the interior, and the interior plants were between $75 \mathrm{~m}$ and $150 \mathrm{~m}$ from the edge. The number of collected leaves varied from 10 to 15 per plant, depending on the size of each plant. Leaves were taken to the laboratory and photographed at a standard distance of $20 \mathrm{~cm}$ using a digital camera (resolution: $2048 \times 1536$ pixels; Canon Powershot A400) to determine their asymmetry levels and leaf areas (physical leaf traits). For photographs, a transparent plate was placed over the leaves to flatten them and minimise distortions (Sinclair and Hoffman, 2003).

To quantify the asymmetry levels, the widths of the right and left sides (from the midrib) in the central portion of each leaf were measured on digitalised photographs using image analysis software (MetaVue, Version 6.3r4). The absolute asymmetry of an individual leaf was defined as the difference between the right width (RW) and the left width (LW) (Palmer and Strobeck, 2003): fluctuating asymmetry of a leaf: $F_{\text {leaf }}=|R W-L W|$. The same photographs and image analysis software were used to measure leaf area $\left(\mathrm{mm}^{2}\right)$.

After being photographed in the laboratory, the leaves were analysed to determine their water, nitrogen, and tannin contents. Water content was determined by measuring the weight difference between fresh and oven-dried leaves (dried at $45{ }^{\circ} \mathrm{C}$ for 72 hours). Fresh weights and digital photographs were obtained immediately after leaf collection. Leaves were milled to a fine powder, and tannins and nitrogen were extracted from $10 \mathrm{mg}$ and $100 \mathrm{mg}$ of dry tissue, respectively. Tannins were quantified by spectrophotometry using an adaptation of the method proposed by Stevanato et al. (2004), in which total phenolics were extracted and tannic acid was used for calibration curve determination. Nitrogen content was determined following the Kjeldahl protocol (AOAC, 1995). Leaves used for biochemical analyses were washed in running water and subsequently rinsed in distilled water before extraction. Three replicates per plant were used for biochemical and statistical analysis.

The entire methodology described above was repeated for adult leaves collected in June 2006 from nine different plants (14 or 15 leaves per plant) from those previously selected. In this case, five plants were on the edge and four were located in the interior. To determine whether physical and chemical leaf traits differed between interior and edge plants, linear mixed effects models were used
(Crawley, 2007) with plants and location (interior and edge) as random and fixed effects, respectively. As water, tannins, and nitrogen concentrations in E. tortuosum leaves change throughout development (Ishino et al., 2011), mixed models were computed separately for young and adult leaves. Linear mixed effects models were run in the $R$ System for Windows, version 2.11.0 (R Development Core Team, 2010).

\subsection{Phenology of E. tortuosum}

The vegetative and reproductive phenologies of 20 individuals of E. tortuosum were evaluated at 15-day intervals from August 2005 until October 2006 for plants that were randomly selected along the four transects. Plant phenology was evaluated by visual inspection (Fournier, 1974), and specific percentages were assigned for each phenological event. Percentages ranged from zero to $100 \%$, with $5 \%$ variation (an adaptation of the Fournier method). For vegetative phenology, the percentages of leaf-buds and young, adult and old leaves were estimated. Old leaves were defined by their dark green colour and much more coriaceous texture compared to young or adult leaves. For reproductive phenology, we calculated the percentages of flower buds, functional flowers, and ripe and unripe fruits. From August 2005 to October 2006, daily data for temperature $\left({ }^{\circ} \mathrm{C}\right)$ and pluvial precipitation $(\mathrm{mm})$ were obtained from the climatological station at the Universidade Estadual Paulista - Unesp/FCA (22 ${ }^{\circ} 48^{\prime} 33^{\prime \prime} \mathrm{S}$ and $48^{\circ} 23^{\prime} 08^{\prime \prime} \mathrm{W}$ ) to check for weather variations over the course of the phenological observations. The study area and the climatological station are about $32 \mathrm{~km}$ apart. Accumulated daily values of precipitation and temperatures (mean, maximum and minimum values) were calculated for each month and represented graphically.

\section{Results and Discussion}

\subsection{Edge effect on leaf traits}

True fluctuating asymmetry is usually verified by whether the RW-LW values of leaves have a normal distribution with zero mean (Palmer and Strobeck, 1986). Normality with a mean different from zero can demonstrate a tendency towards asymmetry in a particular direction, which characterises Directional Asymmetry (DA), and deviations from normality can indicate Anti-Symmetry (AS) (Graham et al., 1998). When DA and AS are demonstrated, they may have an adaptive basis and/or they are determined by still unknown genetic components involved in the normal development of organisms (Palmer and Strobeck, 1986; Palmer, 1994; Van Dongen, 2006). In such cases, neither DA nor AS are treated as estimates of developmental instability. Nevertheless, studying FA on E. tortuosum leaves, Ishino et al. (2011) verified that the RW-LW values were normally distributed, characterising true FA (Palmer and Strobeck, 1986; Graham et al., 1998), and DA was not observed. Because asymmetry may be size-dependent, some studies use correction indices in FA estimations (Hódar, 2002; Freeman et al., 2004; Cornelissen and Stiling, 
2005). However, evidence of size-dependence has not been observed for E. tortuosum leaves (Ishino et al., 2011).

To estimate measurement errors and verify FA data reliability, a random sample of $10 \%$ of all leaves was measured twice (right and left widths). The first and second measurements were subjected to Pearson's correlation because a high correlation coefficient $(r)$ indicates that measurements are reliable (Hódar, 2002). In our study, we observed that the measurement errors for leaf width were very low because data was highly correlated $(r=0.998$; $P<0.0001)$.

It is known that habitat fragmentation causes substantial changes in biotic and abiotic conditions of fragment edges that may change the species richness and abundance of plants and animals (Laurance, 1994; Harrington et al., 2001). In addition, forest fragments historically associated with human activities in the surrounding matrix, such as agricultural practices, may be subject to constant disturbance effects. Results of mixed models showed that nitrogen content, FA and leaf size did not differ significantly between edge and interior plants of the fragment in either young or adult leaves (Table 1). Recent studies have shown a positive relationship between stress and FA levels. For example, after investigating FA on Quercus pyrenaica Willd. (Fagaceae) inhabiting a Mediterranean region, Puerta-Piñero et al. (2008) observed that FA appeared to be a reliable indicator of stress when seedlings were exposed to different levels of light, water and herbivory (stress indicators). However, this leaf trait was unlikely to be determinant for E. tortuosum plants.

A significant decrease in water content was observed in the young leaves of edge plants (Table 1). Increased exposure to light (high photosynthetic rate), wind and high temperatures, commonly observed for plants located at edges (Davies-Colley et al., 2000), probably explains their lower water content. Given that the study area has been surrounded by cultivated crops, it is also possible that the spraying of pesticides and herbicides, the application of fertilisers, and vehicle traffic may have intensified leaf damage and increased the rate of water loss in edge plants.

Young leaves from edge plants had significantly higher tannin levels than those of interior plants (Table 1). It is known that light controls much of the biochemical activity in plant tissues (Harmer et al., 2000; Roberts and Paul, 2006) and significantly influences defence response in plants (Roberts and Paul, 2006). Shading can also reduce concentrations of 'carbon-based defensive chemicals' (CBDCs) such as hydrolysable tannins (Koricheva et al., 1998), and leaf phenolics generally increase with greater insolation in plants examined along a light gradient (Dudt and Shure, 1994). Thus, the high light intensity experienced by E. tortuosum plants located on the edge compared with interior plants may explain the increased tannin levels in edge plants. It is also important to note that high levels of tannins may indicate better-defended plants against insect herbivores (Feeny, 1970; Schoonhoven et al., 2005). This could suggest that edge plants face fewer insect herbivores than interior plants in the early development stages of leaves, reducing their level of stress. Edge plants also had lower water content, suggesting that these plants may be less preferable to insects than interior plants due to their inferior nutritional value (Scriber, 1979; Huberty and Denno, 2004).

Differences in water and tannin concentrations between edge and interior plants were found only in young leaves. It is unclear why these differences were not observed in older foliage (Table 1). One possible explanation is a temporal shift in concentrations of chemical compounds (Salminen et al., 2004; Schoonhoven et al., 2005); at the beginning of the season, young leaves of E. tortuosum have higher levels of water and nitrogen and lower levels of tannins than adult leaves (Ishino et al., 2011). Because E. tortuosum leaves become more coriaceous with age, greater water loss is expected to occur when leaves are young. As a result, differences in water content between edge and interior plants would be more marked early in

Table 1. Comparisons of tannins (mg. $\mathrm{g}^{-1}$ dry weight), nitrogen $\left(\mathrm{g} \cdot \mathrm{kg}^{-1}\right.$ dry weight), water content (\%), leaf area $\left(\mathrm{mm}^{2}\right)$, and fluctuating asymmetry (FA) between leaves from plants located in the interior and on the edge of the fragment. Linear mixed effects models were computed with plants and location (interior or edge) as random and fixed effects, respectively. Analyses were computed for young and adult leaves.

\begin{tabular}{cccrc}
\hline Leaf stage & Response variables & Estimate $(\mathbf{S E})^{\dagger}$ & $t$ & $P$ \\
\hline Young & Tannins & $32.11(11.33)$ & 2.84 & 0.005 \\
& Nitrogen & $0.97(0.71)$ & -2.01 & 0.177 \\
& Water content & $-2.34(1.17)$ & 0.13 & 0.047 \\
& Leaf area & $33.76(253.44)$ & 1.26 & 0.904 \\
Adult & FA & $0.25(0.20)$ & -0.70 & 0.213 \\
& Tannins & $-28.22(40.42)$ & -0.04 & 0.489 \\
& Nitrogen & $-0.04(0.94)$ & -0.96 & 0.361 \\
& Water content & $-1.36(1.43)$ & 0.54 & 0.601 \\
& Leaf area & $138.60(258.40)$ & -0.09 & 0.933 \\
\hline
\end{tabular}

†Values for estimates ( $\mathrm{SE}=$ standard error) are the differences between means from edge plants and interior plants (positive estimate values show high means for edge plants). 
the season, when leaves are still young. According to the carbon/nutrient balance hypothesis, there is a trade-off in the allocation of photosynthate from defence to growth as light declines (Bryant et al., 1983; Coley, 1986; Bryant, 1987; Dudt and Shure, 1994). Based on this hypothesis, it is possible that there were greater investments in early leaf growth in plants located in the interior (shade condition) than in those on the edge; after leaf maturation, high investment in leaf development was no longer necessary, and plants in the interior allocated excess photosynthate to carbon-based phenolics; hence, differences in tannin content between edge and interior plants would not be present in adult leaves. However, the biochemical changes with age in E. tortuosum require further investigation.

Although stress-inducing factors are common in the cerrado (Hoffmann and Moreira, 2002; Miranda et al., 2002), we found no clear evidence that E. tortuosum plants growing at the edge are under higher levels of stress because neither FA nor leaf area differed between edge and interior plants. Differences in chemical concentrations observed between edge and interior plants may be due to other factors, such as light intensity and leaf age, which are not necessarily associated with stress. These results suggest that this species may be stress tolerant, though it is likely that FA and leaf area were not appropriate indicators of environmental stress on E. tortuosum plants. We believe that more data from long-term studies carried out on a large spatial scale are crucial to more precisely determine the stress susceptibility of E. tortuosum and other cerrado plants. Additional studies are encouraged to determine the extent to which the edge effect influences the development of native plant species inhabiting stress-prone systems.

\subsection{Phenology of E. tortuosum}

We observed that leaf-buds were mostly produced in September-October, with numbers decreasing gradually until April (Figures 1a and 2a). Leaf-bud opening increased from the end of September until November, when most leaves were young and coriaceous (Figures 1a and 2b, c); hence, leaf-buds and young leaves were mostly produced during the spring, when temperature and precipitation are moderate (Figure 1c). The greatest production of 'mature' leaves (adult leaves) was observed from January until June (Figure 1a). However, the percentages of adult leaves increased considerably during the rainy season (springsummer), from November/2005 to March/2006, when temperatures are also typically high (Figure 1a, c). After this period, the percentages of mature leaves decreased gradually, followed by an increase in the percentages of old leaves (Figure 1a). The highest percentages of old leaves were observed in the dry season, from May to July (autumn-winter), when lower temperatures are common (Figure 1c). The vegetative events decreased throughout the dry season, from July to August, due to leaf senescence followed by leaf abscission, with full leaf drop occurring between August and the beginning of September (Figures 1a, c). E. tortuosum can therefore be classified as a deciduous plant even though a few old leaves were observed on some plants in the dry season (Ishino et al., 2011).

Reproductive phenology presented more distinct stages than vegetative phenology. Peaks of production of flower buds, unripe (green) and ripe (reddish) fruits were observed in September, October-November and December, respectively (Figures $1 \mathrm{~b}$ and 2d, e). Flower opening was observed from September to November, with a short peak in October (Figures $1 \mathrm{~b}$ and $2 \mathrm{f}$ ). The percentage
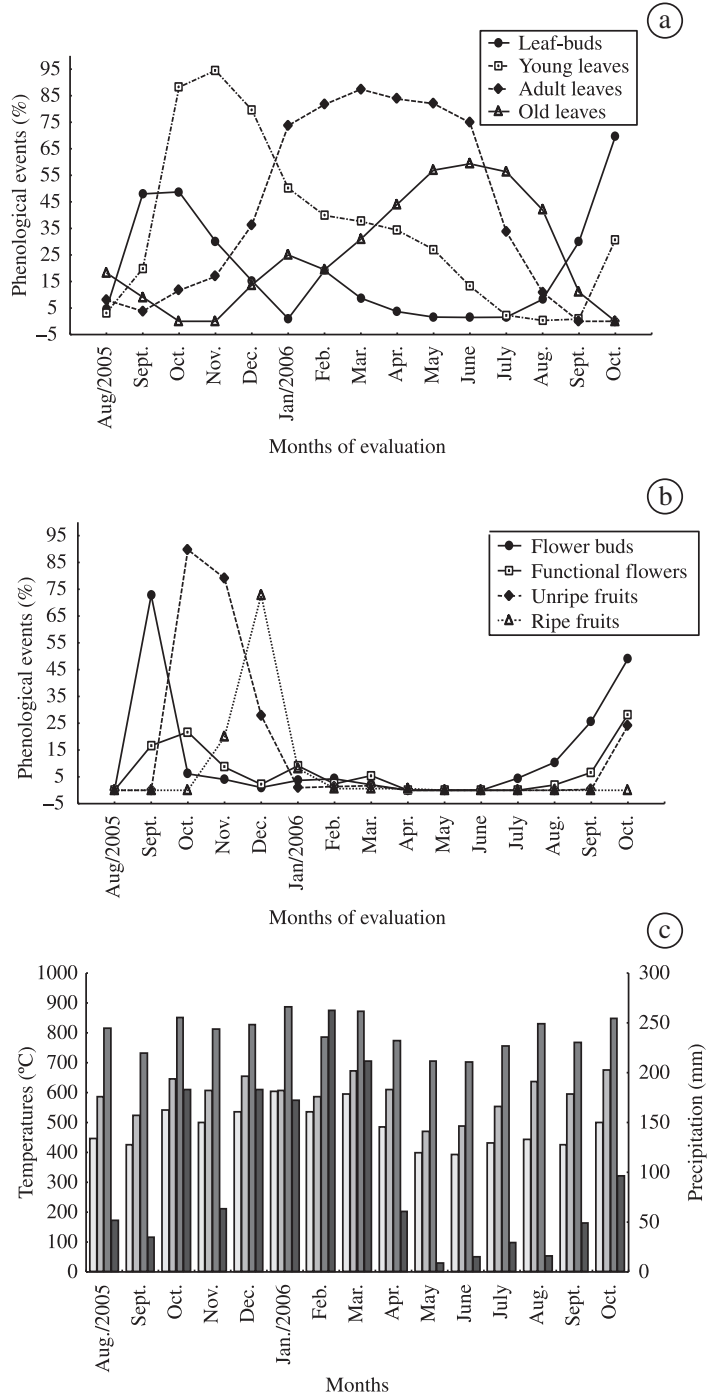

$\square$ Minimum temperature $\square$ Mean temperature $\square$ Maximum temperature Precipitation

Figure 1. Percentage of phenological events (mean values) observed for 20 individuals of E. tortuosum from August 2005 to October 2006. Variations in precipitation and in mean, maximum and minimum temperatures (summation of daily values for each month) are also presented for the period. (a) Vegetative phenology, (b) reproductive phenology, (c) weather data obtained from the climatological station (Unesp/FCA). 

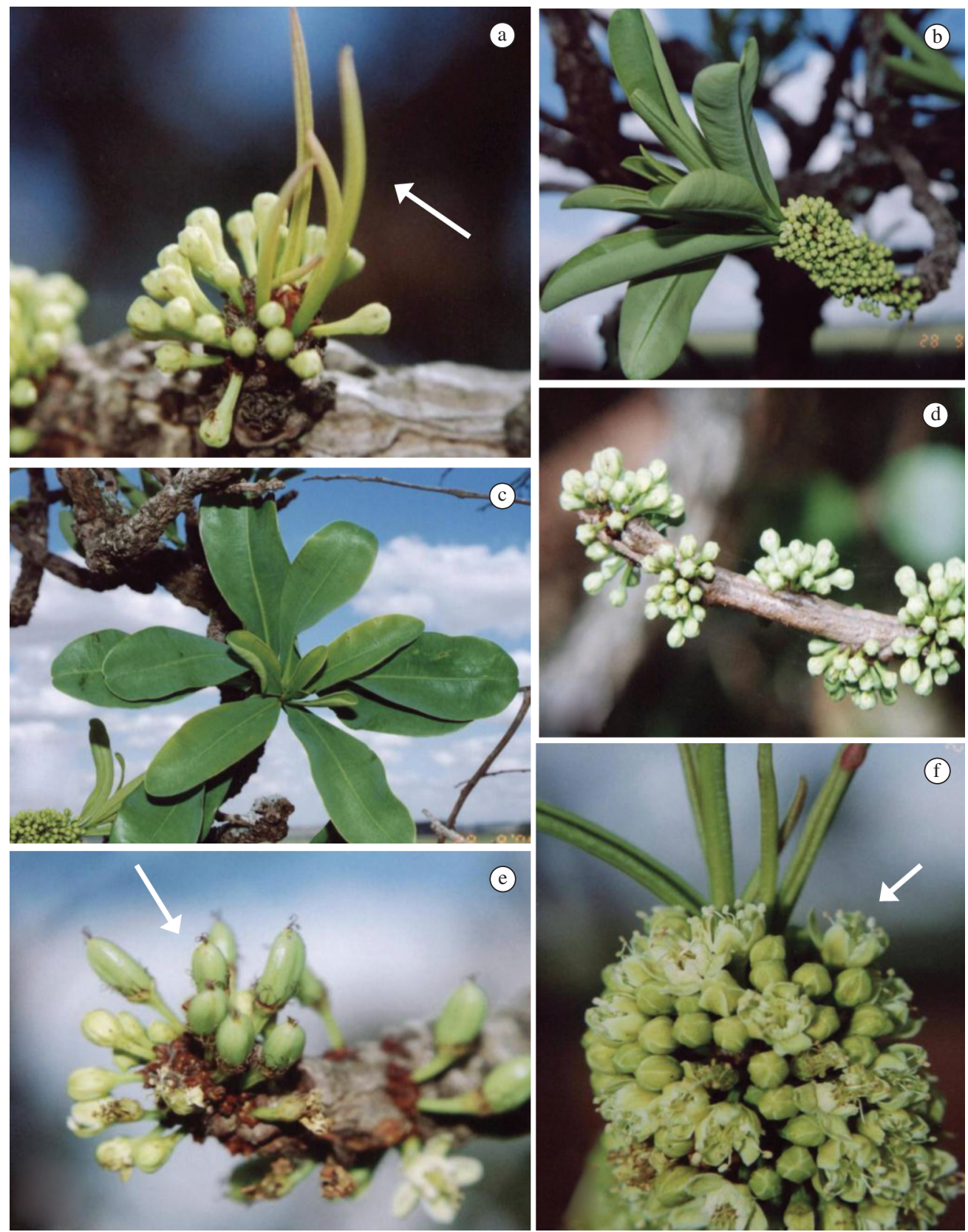

Figure 2. Some phenological events observed for E. tortuosum. (a) Leaf-buds, (b) and (c) young leaves, (d) flower buds, (e) unripe fruits, (f) the opening of flowers.

of functional flowers was relatively low compared with the other reproductive phenological stages. This can be explained by the fact that flowers turned into unripe fruits very quickly. In summary, although $E$. tortuosum plants produced flowers and fruits from August (winter) to January (summer), most reproductive events occurred during the spring (Figures 1b, c).

Acknowledgements - We thank Professor Giuseppina Pace Pereira Lima for helping with the biochemical analysis. M. N. Ishino and M. N. Rossi are particularly grateful to Fapesp (Fundação de Amparo à Pesquisa do Estado de São
Paulo - process number 05/52569-0), and P. R. De Sibio acknowledges Capes (Coordenação de Aperfeiçoamento de Pessoal de Nível Superior), for financial support.

\section{References}

ALADOS, CL., NAVARRO, T., ESCÓS, J., CABEZUDO, B. and EMLEN, JM., 2001. Translational and fluctuating asymmetry as tools to detect stress in stress-adapted and nonadapted plants. International Journal of Plant Sciences, vol. 162, p. 607-616. http://dx.doi.org/10.1086/320130 
Association of Official Analytical Chemists - AOAC, 1995. Official methods of analysis of AOAC Internacional. In CUNIFF, P. (Ed.). AOAC international. Virginia: Arlington. p. 24.

BENÍTEZ-MALVIDO, J. and LEMUS-ALBOR, A., 2005. The seedling community of tropical rain forest edged and its interaction with herbivores and pathogens. Biotropica, vol. 37, p. 301-313. http://dx.doi.org/10.1111/j.1744-7429.2005.00031.x

BIERREGAARD JUNIOR, RO., LOVEJOY, TE., KAPOS, V., SANTOS, AA. and HUTCHINGS, RW., 1992. The biological dynamics of tropical rainforest fragments. BioScience, vol. 42, p. 859-866. http://dx.doi.org/10.2307/1312085

BLACK-SAMUELSSON, S. and ANDERSSON, S., 2003. The effect of nutrient stress on developmental instability in leaves of Acer platanoides (Aceraceae) and Betula pendula (Betulaceae). American Journal of Botany, vol. 90, p. 1107-1112. PMid:21659210. http://dx.doi.org/10.3732/ajb.90.8.1107

BROWN, VK. and LAWTON, JH., 1991. Herbivory and the evolution of leaf size and shape. Philosophical Transactions of the Royal Society of London, Series B-Biological Sciences, vol. 333, p. 265-272. http://dx.doi.org/10.1098/rstb.1991.0076

BRYANT, JP., 1987. Feltleaf willow-snowshoe hare interactions: plant carbon/nutrient balance and floodplain succession. Ecology, vol. 68, p. 1319-1327. http://dx.doi.org/10.2307/1939216

BRYANT, JP., CHAPIN, FS. and KLEIN, DR., 1983. Carbon nutrient balance of boreal plants in relation to vertebrate herbivory. Oikos, vol. 40, p. 357-368. http://dx.doi.org/10.2307/3544308

BURNS, KC. and DAWSON, JW., 2006. A morphological comparison of leaf heteroblasty between New Caledonia and New Zealand. New Zealand Journal of Botany, vol. 44, p. 387-396. http://dx.doi.org/10.1080/0028825X.2006.9513030

COLEY, PD., 1986. Costs and benefits of defense by tannins in a neotropical tree. Oecologia, vol. 70, p. 238-241. http://dx.doi. org/10.1007/BF00379246

CORNELISSEN, T. and STILING, P., 2005. Perfect is best: low leaf fluctuating asymmetry reduces herbivory by leaf miners. Oecologia, vol. 142, p. 46-56. PMid:15378348. http://dx.doi. org/10.1007/s00442-004-1724-y

CORNELISSEN, T., STILING, P. and DRAKE, B., 2003. Elevated $\mathrm{CO}_{2}$ decreases leaf fluctuating asymmetry and herbivory by leaf miners on two oak species. Global Change Biology, vol. 10, p. 27-36. http://dx.doi.org/10.1111/j.1365-2486.2003.00712.x

CRAWLEY, MJ., 2007. The R book. Chichester: John Wiley \& Sons. http://dx.doi.org/10.1002/9780470515075

DAVIES-COLLEY, RJ., PAYNE, GW. and VAN ELSWIJK, M., 2000. Microclimate gradients across a forest edge. New Zealand Journal of Ecology, vol. 24, p. 111-121.

DEL-VAL, E., ARMESTO, JJ., BARBOSA, O. and MARQUET, PA., 2007. Effects of herbivory and patch size on tree seedling survivorship in a fog-dependent coastal rainforest in semiarid Chile. Oecologia, vol. 153, p. 625-632. PMid:17566779. http:// dx.doi.org/10.1007/s00442-007-0778-z

DUDT, JF. and SHURE, DJ., 1994. The influence of light and nutrients on foliar phenolics and insect herbivory. Ecology, vol. 75, p. 86-98. http://dx.doi.org/10.2307/1939385

FAHRIG, L., 2003. Effects of habitat fragmentation on biodiversity. Annual Review of Ecology, Evolution and Systematics, vol. 34, p. 487515. http://dx.doi.org/10.1146/annurev.ecolsys.34.011802.132419

FEENY, P., 1970. Seasonal changes in oak leaf tannins and nutrients as a cause of spring feeding by winter moth caterpillars. Ecology, vol. 51, p. 565-581. http://dx.doi.org/10.2307/1934037
FELFILI, JM. and SILVA-JÚNIOR, MC., 2001. Biogeografia do bioma cerrado: estudo fitofisionômico da Chapada do Espigão Mestre do São Francisco. Brasília: Universidade de Brasília, Faculdade de Tecnologia, Departamento de Engenharia Florestal.

FOURNIER, LA., 1974. Un método cuantitativo para la medición de características fenológicas en árboles. Turrialba, vol. 24, p. $422-423$.

FREEMAN, DC., BROWN, ML., DUDA, J., GRAHAM, JH., EMLEN, JM., KRZYSIK, AJ., BALBACH, H., KOVACIC, DA. and ZAK, JC., 2004. Developmental instability in Rhus Copallinum L.: multiple stressors, years, and responses. International Journal of Plant Sciences, vol. 165, p. 53-63. http://dx.doi.org/10.1086/380986

GRAHAM, JH., EMLEN, JM., FREEMAN, DC., LEAMY, LJ. and KIESER, JA., 1998. Directional asymmetry and the measurement of developmental instability. Biological Journal of the Linnean Society, vol. 64, p. 1-16. http://dx.doi.org/10.1111/j.1095-8312.1998. tb01530.x

GUREVITCH, J., SCHEINER, SM. and FOX, GA., 2002. The ecology of plants. Sunderland: Sinauer Associates.

HANSKI, I., 1999. Metapopulation ecology. Oxford: Oxford University Press.

HARMER, SL., HOGENESCH, JB., STRAUME, M., CHANG, HS., HAN, B., ZHU, T., WANG, X., KREPS, JA. and KAY, SA., 2000. Orchestrated transcription of keypathways in Arabidopsis by the circadian clock. Science, vol. 290, p. 2110-2113. PMid:11118138. http://dx.doi.org/10.1126/science.290.5499.2110

HARRINGTON, GN., FREEMAN, AND. and CROME, FHJ., 2001. The effects of fragmentation of an Australian tropical rain forest on populations and assemblages of small mammals. Journal of Tropical Ecology, vol. 17, p. 225-240. http://dx.doi.org/10.1017/ S0266467401001158

HÓDAR, JA., 2002. Leaf fluctuating asymmetry of Holm oak in response to drought under contrasting climatic conditions. Journal of Arid Environments, vol. 52, p. 233-243. http://dx.doi. org/10.1006/jare.2002.0989

HOFFMANN, WA. and MOREIRA, AG., 2002. The role of fire in population dynamics of woody plants. In OLIVEIRA, PS. and MARQUIS, RJ. (Eds.). The Cerrados of Brazil: ecology and natural history of a neotropical savanna. New York: Columbia University Press. p. 159-177.

HUBERTY, AF. and DENNO, RF., 2004. Plant water stress and its consequences for herbivorous insects - a new synthesis. Ecology, vol. 85, p. 1383-1398. http://dx.doi.org/10.1890/03-0352

ISHINO, MN., DE SIBIO, PR. and ROSSI, MN., 2011. Leaf trait variation on Erythroxylum tortuosum (Erythroxylaceae) and its relationship with oviposition preference and stress by a hostspecific leaf miner. Austral Ecology, vol. 36, p. 203-211. http:// dx.doi.org/10.1111/j.1442-9993.2010.02139.x

KAPOS, V., 1989. Effects of isolation on the water status of forest patches in the Brazilian Amazon. Journal of Tropical Ecology, vol. 5, p. 173-185. http://dx.doi.org/10.1017/S0266467400003448

KORICHEVA, J., LARSSON, S., HAUKIOJA, E. and KEINANEN, M., 1998. Regulation of woody plant secondary metabolism by resource availability: hypothesis testing by means of meta-analysis. Oikos, vol. 83, p. 212-226. http://dx.doi.org/10.2307/3546833

LAURANCE, WF., 1994. Rainforest fragmentation and the structure of small mammal communities in tropical Queensland. Biological Conservation, vol. 69, p. 23-32. http://dx.doi.org/10.1016/00063207(94)90325-5

MARTEL, J., LEMPA, K. and HAUKIOJA, E., 1999. Effects of stress and rapid growth on fluctuating asymmetry and insect 
damage in birch leaves. Oikos, vol. 86, p. 208-216. http://dx.doi. org/10.2307/3546439

MILLIGAN, JR., KREBS, RA. and MAL, TK., 2008. Separating developmental and environmental effect on fluctuating asymmetry in Lythrum salicaria and Penthorum sedoides. International Journal of Plant Sciences, vol. 169, p. 625-630. http://dx.doi. org/10.1086/533600

MILLS, LS., 1995. Edge effects and isolation: red-backed voles on forest remnants. Conservation Biology, vol. 9, p. 395-403. http://dx.doi.org/10.1046/j.1523-1739.1995.9020395.x

MIRANDA, HS., BUSTAMANTE, MMC. and MIRANDA, AC., 2002. The fire factor. In OLIVEIRA, PS. and MARQUIS, RJ. (Eds.). The Cerrados of Brazil: ecology and natural history of a neotropical savanna. New York: Columbia University Press. p. $51-68$

OLIFIERS, N. and CERQUEIRA, R., 2006. Fragmentação de habitat: efeitos históricos e ecológicos. In ROCHA, CFD., BERGALLO, HG., VAN SLUYS, M. and ALVES, MAS. (Eds.). Biologia da conservação: essências. São Carlos: RiMa Editora. p. 261-279.

PAGLIA, AP., FERNANDEZ, FAS. and DE MARCO JUNIOR, P., 2006. Efeitos da fragmentação de habitats: quantas espécies, quantas populações, quantos indivíduos, e serão eles suficientes? In ROCHA, CFD., BERGALLO, HG., VAN SLUYS, M. and ALVES, MAS. (Eds.). Biologia da conservação: essências. São Carlos: RiMa Editora. p. 281-316.

PALMER, AR., 1994. Fluctuating asymmetry analyses: a primer. In MARKOW, TA. (Ed.). Developmental instability: its origins and evolutionary implications. Dordrecht: Kluwer Academic. p. 335-364. http://dx.doi.org/10.1007/978-94-011-0830-0_26

PALMER, AR. and STROBECK, C., 1986. Fluctuating asymmetry: measurement, analysis, patterns. Annual Review of Ecology and Systematics, vol. 17, p. 391-421. http://dx.doi.org/10.1146/annurev. es.17.110186.002135

-, 2003. Fluctuating asymmetry analysis revisited. In POLAK, M. (Ed.). Developmental instability: causes and consequences. New York: Oxford University Press. p. 279-319.

PARSONS, PA., 1990. Fluctuating asymmetry: an epigenetic measure of stress. Biological Reviews of the Cambridge Philosophical Society, vol. 65, p. 131-145. PMid:2190634. http://dx.doi. org/10.1111/j.1469-185X.1990.tb01186.x

POLAK, M., 2003. Developmental instability: causes and consequences. New York: Oxford University Press.

PUERTA-PIÑERO, C., GÓMEZ, JM. and HÓDAR, JA., 2008. Shade and herbivory induce fluctuating asymmetry in a Mediterranean oak. International Journal of Plant Sciences, vol. 169, p. 631-635. http://dx.doi.org/10.1086/533601

R Development Core Team, 2010. R: alanguage and environment for statistical computing. version 2. 11. 0. Vienna: R Foundation for StatisticalComputing.

RIBEIRO, JELS., HOPKINS, MJG., VICENTINI, A., SOTHERS, CA., COSTA, MAS., BRITO, JM., SOUZA, MAD., MARTINS, LHP., LOHMANN, LG., ASSUNÇÃO, PACL., PEREIRA, EC., SILVA, CF., MESQUITA, MR. and PROCÓPIO, LC., 1999. Flora da reserva Ducke: guia de identificação das plantas vasculares de uma floresta de terra firme na Amazônia Central. Manaus: IMPA.
ROBERTS, MR. and PAUL, ND., 2006. Seduced by the dark side: integrating molecular and ecological perspectives on the influence of light on plant defence against pests and pathogens. New Phytologist, vol. 170, p. 677-699. PMid:16684231. http:// dx.doi.org/10.1111/j.1469-8137.2006.01707.x

RODRIGUES, TM. and MACHADO, SR., 2008. Pulvinus functional traits in relation to leaf movements: a light and transmission electron microscopy study of the vascular system. Micron, vol. 39, p. 7-16. PMid:17950612. http://dx.doi.org/10.1016/j.micron.2007.09.001

ROSLIN, T., GRIPENBERG, S., SALMINEN, JP., KARONEN, M., O'HARA, RB., PIHLAJA, K. and PULKKINEN, P., 2006. Seeing the trees for the leaves - oaks as mosaics for a host-specific moth. Oikos, vol. 113, p. 106-120. http://dx.doi.org/10.1111/j.00301299.2006.14460.x

SALMINEN, JP., ROSLIN, T., KARONEN, M., SINKKONEN, J., PIHLAJA, K. and PULKKINEN, P., 2004. Seasonal variation in the content of hydrolysable tannins, flavonoid glycosides, and proanthocyanidins in oak leaves. Journal of Chemical Ecology, vol. 30, p. 1693-1711. PMid:15586669. http://dx.doi. org/10.1023/B:JOEC.0000042396.40756.b7

SCHOONHOVEN, LM., VAN LOON, JJA. and DICKE, M., 2005. Insect-plant biology. New York: Oxford University Press.

SCRIBER, JM., 1979. Effects of leaf-water supplementation upon post-ingestive nutritional indices of forb-, shrub-, vine-, and treefeeding Lepidoptera. Entomologia Experimentalis et Applicata, vol. 25, p. 240-255. http://dx.doi.org/10.1111/j.1570-7458.1979. tb02876.x

SELIGMANN, P., MITTERMEIER, RA., DA FONSECA, GAB., GASCON, C., CRONE, N., DA SILVA, JMC., FAMOLARE, L., BENSTED-SMITH, R., RAJAOBELINA, L. and BEEHLER, B., 2007. Centers for biodiversity conservation: bringing togetherscience, partnerships, and human well-being to scale up conservation outcomes. Arlington: Conservation International.

SHI, G. and CAI, Q., 2009. Leaf plasticity in peanut (Arachis hypogaea L.) in response to heavy metal stress. Environmental and Experimental Botany, vol. 67, p. 112-117. http://dx.doi. org/10.1016/j.envexpbot.2009.02.009

SINCLAIR, C. and HOFFMANN, AA., 2003. Monitoring salt stress in grapevines: are measures of plant trait variability useful? Journal of Applied Ecology, vol. 40, p. 928-937. http://dx.doi. org/10.1046/j.1365-2664.2003.00843.x

STEVANATO, R., FABRIS, S. and MOMO, F., 2004. New enzymatic method for the determination of total phenolic content in tea and wine. Journal of Agricultural and Food Chemistry, vol. 52, p. 6287-6293. PMid:15453702. http://dx.doi.org/10.1021/jf049898s

VAN DONGEN, S., 2006. Fluctuating asymmetry and developmental instability in evolutionary biology: past, present and future. Journal of Evolutionary Biology, vol. 19, p. 1727-1743. PMid:17040371. http://dx.doi.org/10.1111/j.1420-9101.2006.01175.x

WANDERLEY, MGL., SHEPHERD, GJ. and GIULIETTI, AM., 2002. Flora fanerogâmica do Estado de São Paulo. São Paulo: Hucitec, Fapesp. vol. 2.

WHITE, TCR., 1984. The abundance of invertebrate herbivory in relation to the availability of nitrogen in stressed food plants. Oecologia, vol. 63, p. 90-105. http://dx.doi.org/10.1007/BF00379790 